\title{
Riders on the Storm: Selective Tidal Movements Facilitate the Spawning Migration of Threatened Delta Smelt in the San Francisco Estuary
}

\author{
W. A. Bennett • J.R. Burau
}

Received: 5 May 2014 /Revised: 13 August 2014 / Accepted: 26 August 2014 /Published online: 23 September 2014

(C) The Author(s) 2014. This article is published with open access at Springerlink.com

\begin{abstract}
Migration strategies in estuarine fishes typically include behavioral adaptations for reducing energetic costs and mortality during travel to optimize reproductive success. The influence of tidal currents and water turbidity on individual movement behavior were investigated during the spawning migration of the threatened delta smelt, Hypomesus transpacificus, in the northern San Francisco Estuary, California, USA. Water current velocities and turbidity levels were measured concurrently with delta smelt occurrence at sites in the lower Sacramento River and San Joaquin River as turbidity increased due to first-flush winter rainstorms in January and December 2010. The presence/absence of fish at the shoal-channel interface and near the shoreline was quantified hourly over complete tidal cycles. Delta smelt were caught consistently at the shoal-channel interface during flood tides and near the shoreline during ebb tides in the turbid Sacramento River, but were rare in the clearer San Joaquin River. The apparent selective tidal movements by delta smelt would facilitate either maintaining position or moving upriver on flood tides, and minimizing advection down-estuary on ebb tides. These movements also may reflect responses to lateral gradients in water turbidity created by temporal lags in tidal velocities between the near-shore and mid-channel habitats. This migration strategy can minimize the energy spent swimming
\end{abstract}

Communicated by Judy Grassle

W. A. Bennett $(\bowtie)$

Center for Watershed Sciences, Bodega Marine Laboratory, University of California, Davis, P.O Box 247, Bodega Bay, CA 94923, USA

e-mail: wabennett@ucdavis.edu

J. Burau

California Water Science Center, U.S. Geological Survey,

6000 J Street, Sacramento, CA 95819-6129, USA against strong river and tidal currents, as well as predation risks by remaining in turbid water. Selection pressure on individuals to remain in turbid water may underlie population-level observations suggesting that turbidity is a key habitat feature and cue initiating the delta smelt spawning migration.

Keywords Selective tidal movements · Tidal currents · Turbidity $\cdot$ Migration $\cdot$ Endangered species $\cdot$ San Francisco Estuary

\section{Introduction}

Migration is a widespread life history strategy that optimizes the use of spatial and temporal variability in habitat quality to increase reproductive success and fitness of individuals (Dingle 1996). Characterizing this fascinating and complex phenomenon involves perspectives at various levels of biological organization, such that migration is most readily defined by the behavior of individuals, but then only fully understood in terms of population outcomes or consequences (Roff 1992; Dingle 1996). For fishes in estuarine and river systems, recent work has focused on quantifying cost/benefit trade-offs underlying the evolution of migration strategies. For any specific strategy to persist, the potential benefits (e.g., foraging and reproductive success) must outweigh the substantial costs in time and metabolic energy expended, as well as the added risks of mortality (e.g., predation) during migration (Jonsson and Jonsson 1993; Bronmark et al. 2008; Chapman et al. 2013). Theoretical and empirical studies (Roff 1988; Jorgensen et al. 2008) suggest migrants ameliorate costs through adaptive responses in various traits, including ecological (Schaffer and Elson 1975; Jonsson and Jonsson 2006), morphological (Crossin et al. 2004; Jonsson and Jonsson 2006), and behavioral (Hinch and Rand 2000; 
McElroy et al. 2012; Keefer et al. 2013). Accordingly, selection pressure to conserve energy for reproduction is more likely to be stronger on smaller or long-distance migrants and when spawning occurs soon after migrating (Kinnison et al. 2001; Crossin et al. 2004; Jonsson and Jonsson 2006).

Behavioral responses used by fishes to optimize cost/benefit trade-offs are often triggered by external cues and can include individual assessments of body condition and maturity level, as well as strategies for swimming against strong river and tidal currents (Brodersen et al. 2008a, b; Forsythe et al. 2012). Typically, external cues signal optimal times and routes for traveling that minimize predation risks and promote reproductive success. Thus, cues initiating migration are often somewhat predictable, including annual and monthly lunar cycles (Forsythe et al. 2012), seasonal water temperatures (Quinn and Adams 1996; Dahl et al. 2004), as well as tidal currents and river outflows (Anderson and Beer 2009; Forsythe et al. 2012). For many species, the energetic costs of swimming are tremendous. Atlantic salmon (Salmo salar) have been estimated to lose between 60 and $70 \%$ of their energy reserves during migration and spawning (Jonsson et al. 1997), whereas sockeye salmon (Onchorynchus nerka) can use up to $84 \%$ of their total energy reserves for swimming (Hinch and Rand 1998). This suggests that there is strong selection pressure to adjust travel speeds and distances, as well as position in tidal currents to conserve energy for reproduction. For example, sockeye salmon travel upriver in narrow bands near the shoreline where current speeds are lower than mid-channel (Hinch and Rand 2000), and Pallid sturgeon (Scaphirhynchus albus) appear to zigzag across river channels taking advantage of weaker currents on the inside of river bends as they migrate (McElroy et al. 2012).

In the present study, we investigate the effect of tidal currents and water quality variables (e.g., turbidity) on the individual movement behaviors used during the spawning migration by the threatened delta smelt, $H$. transpacificus, endemic to the northern San Francisco Estuary (SFE), California, USA. (Fig. 1). This small $(<90 \mathrm{~mm})$ semianadromous species is primarily an annual with a few individuals living to spawn in a second spring. Delta smelt was abundant historically, but declined dramatically over the last three decades, such that it is now protected under the California state and federal Endangered Species Act (ESA, USFWS 1993). Relatively little is known about spawning and reproduction in nature; adhesive embryos spawned by delta smelt have never been found (Moyle et al. 1992; Bennett 2005). Spawning in most years occurs primarily in the upper freshwater portions of the northern Delta during spring (March-June), with larvae and juveniles dispersing and rearing in the tidal freshwater to the low-salinity zone $(<12)$ of the system (Fig. 1). This region expands to encompass Suisun Bay in years with moderate to high freshwater outflow and contracts in dry, or drought, conditions to include only the Delta (Bennett 2005, Fig. 1). During fall (September-
November), maturing adults reside primarily in the lowsalinity zone which also maintains elevated water turbidity relative to elsewhere due to wind-wave resuspension occurring over two large shallow $(<3 \mathrm{~m})$ sub-embayments, Grizzly and Honker Bays (Ruhl et al. 2001, Fig. 1).

Delta smelt undertake an annual spawning migration that appears to begin immediately following the arrival of turbid water from land runoff mobilized by the first major winter (December-February) rainstorm, the so-called first flush (Bergamaschi et al. 2001; Grimaldo et al. 2009; Sommer et al. 2011). The sudden increase in turbidity may reduce predation risks, signaling the optimal time for traveling upriver (about 15-20 km) to spawning habitat in the northern Delta (Grimaldo et al. 2009; Sommer et al. 2011). Although turbidity is a readily apparent cue associated with the delta smelt migration, other potentially co-occurring and interactive processes also may be involved (Rakowitz et al. 2008).

Our objectives were to (1) evaluate individual movement behavior in relation to the prevailing hydrodynamics at tidal time scales to understand how this small pelagic fish is able to travel upriver against strong river and tidal flows (ca. $1,800 \mathrm{~m}^{3} \mathrm{~s}^{-1}$ ) and (2) explore if processes observed at the individual and tidal scales can help to explain the apparent roles of turbidity as a habitat feature (Feyrer et al. 2007) and a cue for the spawning migration at the population level (Grimaldo et al. 2009; Sommer et al. 2011). Here, we distinguish movements as those made by individuals over a few meters at tidal time scales, and migration as a distributional shift occurring annually over kilometers and months at the population level. Our study occurred in two consecutive winters, integrating monitoring of hydrodynamics, water turbidity, salinity, and temperature, concurrently with sampling for fish. Understanding how individual behaviors interact with tidal currents and water quality is essential to gain insight into the processes promoting pelagic habitat for estuarine species and the evolution of migration.

\section{Methods}

\section{Study Area}

The Delta region of the SFE is composed of a complicated network of tidally forced channels and canals that is considered one of the most highly altered terminal floodplain ecosystems (Lund et al. 2010, Fig. 1). The Delta is used primarily to transfer freshwater from the Sacramento River in the north and San Joaquin River in the south to central and southern California via canals of the State Water Project and Central Valley Project (Lund et al. 2010, Fig. 1). The diverted freshwater supports production of about one half of the fruits and vegetables in the USA and provides drinking water for about 25 million Californians. Water-exporting operations, however, 


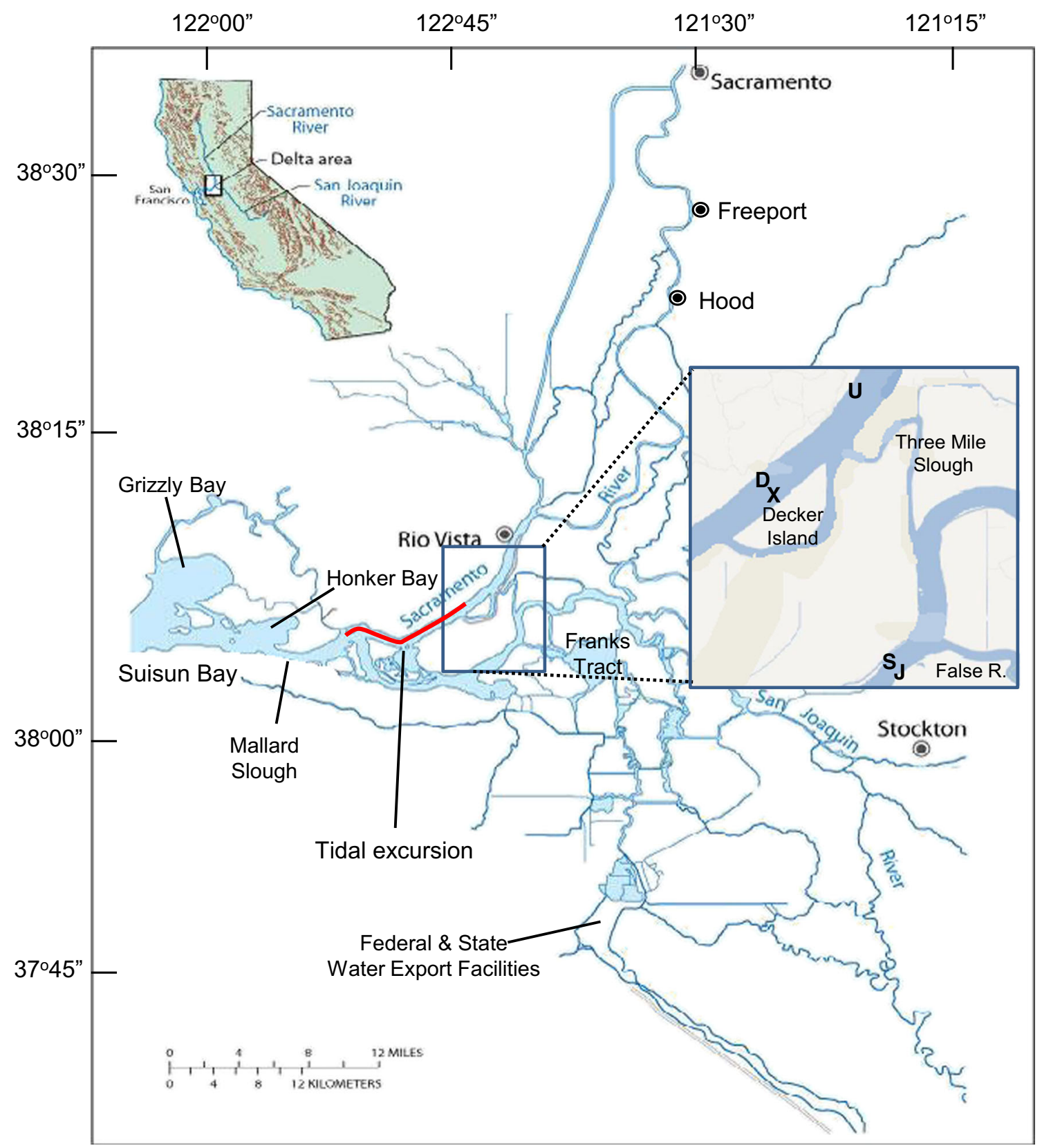

Fig. 1 Map of study area in the lower Sacramento River and San Joaquin River in the northern San Francisco Estuary, CA, USA. Letters show location of sampling stations and typical tidal excursion (thick line)

also kill large numbers of fish, including delta smelt (Kimmerer 2008; Grimaldo et al. 2009). ESA regulations intended to minimize entrainment mortality of delta smelt often restrict water-exporting operations and interfere with allocations of freshwater throughout California, which has unfortunately intensified controversy and litigation focusing on this imperiled species.

\section{Study Design}

Our study was conducted in the lower Sacramento River and San Joaquin River, two potential migration routes for delta smelt in the western Delta (Fig. 1). While the Sacramento River is likely the primary route, in some years, individuals enter the San Joaquin River and travel through the central Delta, which increases the chance of entrainment in the water export facilities (Grimaldo et al. 2009). Our fieldwork coincided with the first major winter storms producing the first flush and occurred on January 27-28, 2010 and then December 21, 2010 to January 1, 2011. Sampling integrated continuous monitoring of hydrodynamics, water turbidity, salinity, and temperature, concurrently with sampling for fish to quantify the pelagic microhabitat typically used by delta smelt at tidal time scales. Based on velocity measurements 
taken at this location using a horizontal acoustic Doppler profiler (Burau, unplublished data), we decided to sample hourly at fixed locations. This would enable sampling of 8 $12 \mathrm{~km}$ of river water and fish habitat as it moved past our position by strong tidal currents (ca. $85 \mathrm{~cm} \mathrm{~s}^{-1}$ ) over a complete tidal cycle, depending on the spring/neap lunar phase (Fig. 1).

During the January 2010 study, hereafter referred to as the Pilot Study, sampling occurred only near Decker Island in the lower Sacramento River (D, Fig. 1), whereas during the following winter (December 2010), sampling alternated daily between sites in the Sacramento River and those near Jersey Point in the San Joaquin River (Fig. 1). The bathymetry in this reach of the Sacramento River is relatively prismatic (i.e., uniform in cross section) within about $18 \mathrm{~km}$ of our sampling location, because it was completely man-made by dredging during the late 1800 s for flood control. Thus, because this reach of the river is wide (ca. $900 \mathrm{~m}$ ), relatively shallow (ca. $10 \mathrm{~m}$ ), and prismatic, it has very weak lateral mixing and other potential complicating hydrodynamic factors; particles released in this region tend to return to their original release point on subsequent tide (Fischer et al. 1979; Nidzieko et al. 2009). This facilitates separating behavioral responses from hydrodynamic influences on responses of fish to changes in tidal current direction and water clarity. In contrast, the hydrodynamics at the San Joaquin location are more complex, with water mixed by secondary currents in nearby bends and exchanging with side channels such that it can come from different regions of the Delta (Fig. 1).

In the Sacramento River, we chose our sampling sites along the northwestern side of the river just inside the channel marker buoys, where tidal fronts regularly occur at the shoal-channel interface (Fig. 1). Our rationale was based on the well-documented observation that a variety of pelagic organisms, including small fishes, tend to exploit open-water habitat by aggregating at tidal fronts (Owen 1981; Maravelias and Reid 1997; Marchand et al. 1999). A horizontal acoustic Doppler current profiler (H-ADCP, ChannelMaster, Teledyne RD Instruments) calibrated using the index velocity method (Ruhl and Simpson 2005; Coz et al. 2008) was deployed from a channel marker and continuously monitored river discharge and tidal current velocity distribution at mid-depth; electrical conductivity, temperature, and turbidity were also measured using a 6,600 V2-4 MultiSonde (YSI, Inc.) and available in real-time throughout the study via a RavenXTV CDMA Sierra Wireless Cellular Modem (Campbell Scientific, Inc.). Additional water current velocity and turbidity data (e.g., used in Fig. 2) collected by the U.S. Geological Survey were measured as part of the Interagency Ecological Program's continuous monitoring program (http://www.water.ca.gov/iep/).

Overall, sampling for fish occurred hourly over $12-16 \mathrm{~h}$, to encompass complete tidal cycles which varied in duration

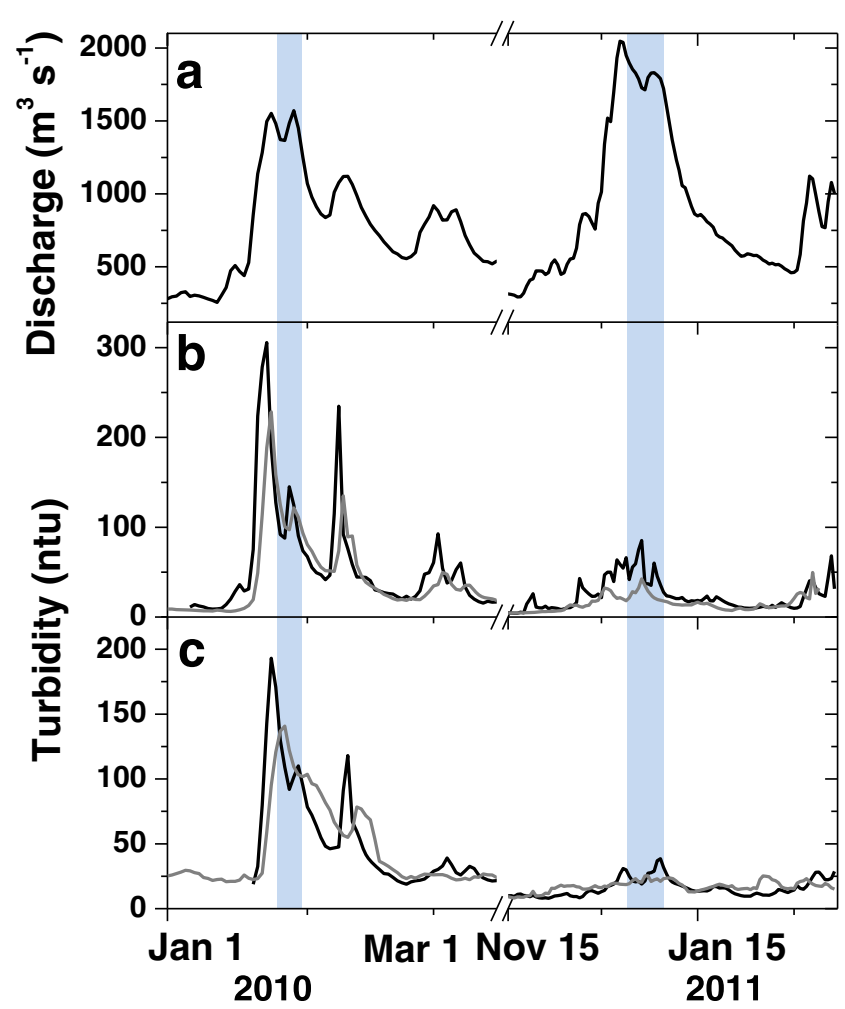

Fig. 2 Sacramento River flow (a) and turbidity levels at Freeport (black line) and Rio Vista (gray line) (b), as well as Decker Island (black) and Mallard Slough (gray) in the lower San Joaquin River (c) from January 2010 to March 2011. Vertical shading shows both study periods

with the magnitudes of river flow and the tides. Each day of sampling required several field crews working concurrently at different locations and began at the top of the hour nearest time of slack water estimated using the real-time data from the hydrodynamic instruments. Fish were sampled in the upper $4 \mathrm{~m}$ of the water column using Kodiak trawls, which involves towing a $7.6 \times 1.8-\mathrm{m}$ net with mesh that tapers from $50 \mathrm{~mm}$ at the mouth to $6 \mathrm{~mm}$ at the cod end. This presents a crosssectional area of about $14 \mathrm{~m}^{2}$ when the net is stretched between two boats running in parallel. During each winter study, a crew with a Kodiak trawl sampled hourly at station D near Decker Island in the lower Sacramento River (Fig. 1). In the December 2010 study, another crew also sampled concurrently with a $15.2 \times 1.2-\mathrm{m}$ beach seine with a $3-\mathrm{mm}$ mesh along the adjacent shoreline at station $\mathrm{D}$, with an additional Kodiak trawl and beach seine crews also sampling immediately upriver, near Three Mile Slough (station U, Fig. 1). Station U was located about one third of the distance of the maximum tidal excursion from station D (Fig. 1). If delta smelt were caught at station $\mathrm{D}$ during the flood tide, we might expect to detect them at station $U$ after a few hours if fish were moving upriver with the incoming tide. The crew sampling at station $\mathrm{U}$ alternated hourly with station $\mathrm{X}$, located mid-channel directly offshore from station D to assess the extent to which delta smelt were distributed laterally (Fig. 1). 
Table 1 Numbers of fish caught in Kodiak trawl and beach or purse seines in the Sacramento and San Joaquin Rivers on January 27-28, 2010 (1/10) and from December 21, 2010 to January 1, 2011 (12/10-1/11)

\begin{tabular}{|c|c|c|c|c|c|c|}
\hline \multirow[t]{2}{*}{ Species } & \multicolumn{3}{|c|}{ Sacramento River } & \multicolumn{3}{|l|}{ San Joaquin River } \\
\hline & Kodiak & 1012/10-1/11 & Beach Seine & Kodiak Trawl & Purse seine & Total \\
\hline Delta smelt Hypomesus transpacificus ${ }^{\mathrm{a}}$ & 225 & 479 & 176 & 3 & 0 & 883 \\
\hline Threadfin shad Dorosoma petenense & 73 & 359 & 182 & 38 & 13 & 665 \\
\hline Chinook salmon Oncorhyncus tshawytscha ${ }^{\mathrm{a}}$ & 129 & 237 & 1,594 & 13 & 5 & 1,978 \\
\hline Mississippi silverside Menidia beryllina & 35 & 151 & 821 & 5 & 55 & 1,067 \\
\hline Pacific lamprey Lampetra tridentata ${ }^{\mathrm{a}}$ & 7 & 59 & 0 & 0 & 0 & 66 \\
\hline Longfin smelt Spirinchus thaleichthys ${ }^{\mathrm{a}}$ & 20 & 48 & 7 & 0 & 0 & 75 \\
\hline American shad Alosa sapidissima & 6 & 27 & 0 & 15 & 0 & 48 \\
\hline Bluegill Lepomis macrochirus & 5 & 9 & 8 & 7 & 1 & 30 \\
\hline River lamprey Lampetra ayresi ${ }^{\mathrm{a}}$ & 1 & 11 & 0 & 0 & 0 & 12 \\
\hline Tule perch Hysterocarpus traski $i^{\mathrm{a}}$ & 1 & 1 & 20 & 4 & 62 & 88 \\
\hline Striped bass Morone saxatilis & 2 & 3 & 639 & 0 & 293 & 937 \\
\hline Splittail Pogonichthys macrolepidotus ${ }^{\mathrm{a}}$ & 13 & 4 & 59 & 0 & 24 & 100 \\
\hline Sacramento pikeminnow Ptychocheilus grandis ${ }^{\mathrm{a}}$ & 15 & 0 & 26 & 1 & 1 & 43 \\
\hline Yellowfin goby (Acanthogobius flavimanus) & 0 & 3 & 21 & 2 & 8 & 34 \\
\hline Wakasagi Hypomesus nipponensis & 3 & 3 & 17 & 0 & 1 & 24 \\
\hline Bigscale logperch Percina macrolepida & 0 & 0 & 1 & 0 & 46 & 47 \\
\hline Hitch Lavinia exilicauda ${ }^{\mathrm{a}}$ & 0 & 0 & 12 & 0 & 11 & 23 \\
\hline Redear sunfish Lepomis microlophis & 0 & 0 & 4 & 0 & 3 & 7 \\
\hline Shimofuri goby Tridentiger bifasciatus & 2 & 3 & 7 & 0 & 0 & 12 \\
\hline Rainbow trout Oncorhynchus mykiss ${ }^{\mathrm{a}}$ & 7 & 2 & 0 & 0 & 0 & 9 \\
\hline Largemouth bass Micropterus salmoides & 0 & 1 & 0 & 1 & 2 & 4 \\
\hline
\end{tabular}

Only Kodiak trawls were used during the $1 / 10$ sampling

${ }^{\text {a }}$ Denote 513 native species

Every other day during the December 2010 study, we sampled in the San Joaquin River with a Kodiak trawl crew that alternating hourly between station $\mathrm{S}$, at the shoal-channel interface, and station $\mathrm{J}$, located on the opposite side of the main channel (Fig. 1). These two locations were chosen so that we sampled water that exchanged into different regions of the central Delta. For example, on ebb tides, water at station $\mathrm{S}$ is transported from the San Joaquin River, whereas at station J, water arrives from the southern Delta via the False River (Fig. 1). Thus, by sampling laterally at this single location, we could compare and contrast two distinct routes of potential fish transport, assuming fish move with the water. If delta smelt were detected at station J, the prevailing hydrodynamics associated with dispersive mixing in Franks Tract would substantially increase the probability for these fish to become vulnerable to the major water export facilities in the south Delta (Fig. 1). At station S, a separate crew used a $30-\mathrm{m}$ purse seine with a $5-\mathrm{mm}$ mesh to sample near the shoreline because of the logistical difficulties associated using a beach seine at this location.

Given that both delta smelt and winter run Chinook salmon, Oncorhynchus tshawytscha, co-occurred in our study area and are both protected under the federal ESA, strict fish-take limits were imposed with catch reported daily to the regulatory agencies. Although delta smelt occur in very low densities, we closely monitored catch and adjusted sampling effort (tow durations) in real time to avoid excessive take of these species. Thus, we tailored sampling to reliably detect delta smelt presence/absence rather than quantify overall density. All fish caught during sampling were first identified and measured for length. The majority of juvenile Chinook salmon were then released immediately unharmed, as were other fishes in the catch. About $30 \%$ of the delta smelt in the catch appeared unharmed and were swimming normally after capture, thus were also released. Although fewer individuals of this fragile species survived relative to others, the proportion released was higher than anticipated and likely due to reducing trawl durations from 15 to $10 \mathrm{~min}$. The remaining delta smelt were then coded and individually rolled up in aluminum foil and placed into a dewar containing liquid nitrogen and archived. Hydrodynamic and delta smelt catch data were initially explored using various graphical techniques. Generalized linear modeling (GLM) was then used to evaluate an apparent association between tidal current direction and delta smelt catch. 
Fig. 3 Trends in turbidity (thick line) and light intensity $(a)$ with delta smelt catch at shoal-channel margin (dark bars) and near the shoreline (gray bars) in relation to tidal and river flows $(b)$, from the December 2010 field sampling in the Sacramento River. Negative water velocity represents flood tides

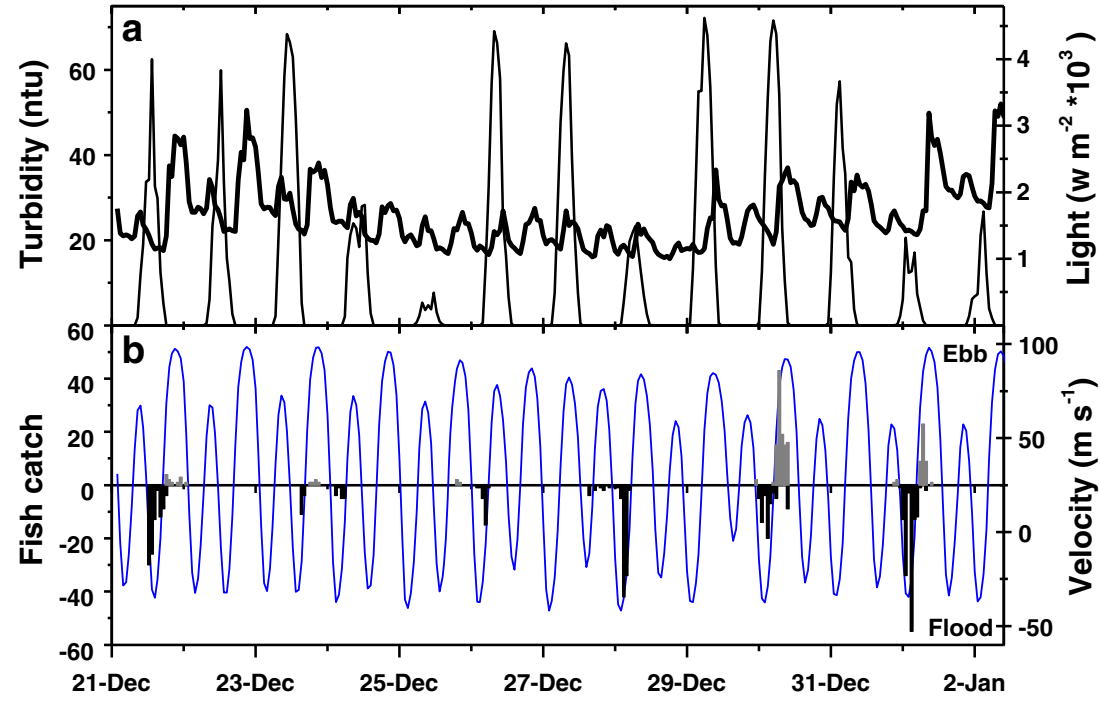

\section{Results}

\section{Physical Conditions}

Patterns of rainfall, river discharge, and turbidity differed substantially between the two winter study periods (Fig. 2). During the 2009-2010 winter of the Pilot Study, river flows were relatively low, peaking at only about $1,557 \mathrm{~m}^{3} \mathrm{~s}^{-1}$ (Fig. 2(a)), but were apparently sufficient to mobilize higher levels of turbidity ( $\sim 350$ nephelometric turbidity units (NTU) at Freeport, Fig. 2(b)) than those observed in the following winter season. After the December 2010 "first flush" rainstorm, however, turbidity levels were far lower than anticipated ( $50-80 \mathrm{NTU})$ at our Sacramento River study area and did not increase in the San Joaquin River (Fig. 2(b, c)). This was surprising given that flows in the Sacramento River peaked at $2,124 \mathrm{~m}^{3} \mathrm{~s}^{-1}$ (Fig. 2). These unusually low turbidity levels likely resulted from intentional releases of relatively clear water from reservoirs in the upper watershed to accommodate the large volumes of runoff projected from this storm. The reservoir releases were substantial, constituting $30-80 \%$ of the flow in the Sacramento River during December-January, whereas they typically only make up about $10 \%$ of the river flow. As a result, the slight increases in turbidity observed in the lower Sacramento River were derived from turbid water extending upriver on flood tides to our study area from Suisun Bay, given that the highest levels occurred primarily during flood tides.

Table 2 Results of alternative generalized linear models associating delta smelt occurrence with environmental conditions at the shoal-channel margin versus the near the shoreline, including $z$-statistics, probabilities of significance, and Akaike Information Criteria (AIC)

\begin{tabular}{|c|c|c|c|c|c|c|}
\hline \multirow[t]{2}{*}{ Model } & \multicolumn{6}{|l|}{ Variable } \\
\hline & Velocity (CMS) & Turbidity (NTU) & Hour (h) & Year & $\mathrm{CMS} \times \mathrm{NTU}$ & AIC \\
\hline \multicolumn{7}{|l|}{ Channel margin } \\
\hline CMS & $-5.78 * * *$ & & & & & 127 \\
\hline NTU & & $-3.98 * * *$ & & & & 153 \\
\hline $\mathrm{CMS}+\mathrm{NTU}$ & $-5.09 * * *$ & $-2.39 *$ & & & & 122 \\
\hline $\mathrm{CMS}+\mathrm{NTU}+\mathrm{h}$ & $-4.37 * * *$ & $-2.41^{*}$ & -0.813 & & & 124 \\
\hline $\mathrm{CMS}+\mathrm{NTU}+$ Year & $-4.15 * * *$ & $-2.41^{*}$ & & 1.16 & & 123 \\
\hline $\mathrm{CMS}+\mathrm{NTU}+\mathrm{CMS} \times \mathrm{NTU}$ & $-2.59 * *$ & $-2.09^{*}$ & & & 1.19 & 123 \\
\hline \multicolumn{7}{|l|}{ Shoreline } \\
\hline CMS & $4.24 * * *$ & & & & & 76 \\
\hline NTU & & $3.96^{* * *}$ & & & & 92 \\
\hline $\mathrm{CMS}+\mathrm{NTU}$ & $3.22 * *$ & 0.36 & & & & 78 \\
\hline $\mathrm{CMS}+\mathrm{h}$ & $3.82 * * *$ & & 1.03 & & & 77 \\
\hline
\end{tabular}

${ }^{*} p<0.05 ; * * p<0.01 ; * * * p<0.001$ 
Fish Catch

Overall, 21 fish species were collected during the two winter sampling periods, with catch composition varying greatly between the Sacramento River and San Joaquin River, as well as in the Kodiak trawls versus the beach or purse seines (Table 1). Pelagic species, such as delta smelt and threadfin shad, Dorosoma petenense, were most abundant in the Kodiak trawls, whereas juvenile Chinook salmon and Mississippi silversides, Menidia beryllina, dominated the catch in the shoreline sampling. During the Pilot Study, 225 delta smelt and 129 juvenile Chinook salmon were caught in the Pilot Study, with 655 and 1,831 of each species respectively caught during the December 2010 sampling period. Juvenile Chinook salmon and Mississippi silversides, M. beryllina, dominated the catch in the shoreline sampling. In contrast, only 3 delta smelt and 18 juvenile Chinook salmon were caught at the San Joaquin River locations (Table 1).

Delta smelt were caught fairly consistently by focusing our sampling near the shoal-channel interface during both the Pilot Study and the December 2010 study period. At this location (D, Fig. 1), $82 \%$ of net tows occurring on flood tides detected delta smelt relative to $67 \%$ of samples taken nearby at the mid-channel station (X, Fig. 1). The higher detection of delta smelt at the interface facilitated identifying a clear tidal signal in the catch time series, such that during flood tides, delta smelt were caught almost exclusively in the Kodiak trawls, whereas on ebb tides, they were primarily caught in the beach seines at the shoreline stations (Fig. 3). Delta smelt catch in the Kodiak trawls was also somewhat higher when turbidity levels were elevated and in the morning (Fig. 3).

Generalized linear models with a binomial error distribution and a logit link function (i.e., logistic regression) were used to associate delta smelt occurrence (i.e., presence/absence) in the Kodiak trawls and beach seines with tidal velocity, water turbidity, time of day, and calendar year sampled as predictor variables (Table 2). Overall, variability in water temperatures and specific conductance was low, averaging $10{ }^{\circ} \mathrm{C}\left(\right.$ range $\left.=1.8{ }^{\circ} \mathrm{C}\right)$ and $116 \mu \mathrm{S} \mathrm{cm}^{-1}$ (range $=$ $149 \mu \mathrm{S} \mathrm{cm}^{-1}$ ), respectively. In preliminary analyses, both factors were not significant predictors, thus were not included in the final analyses. For the Kodiak trawl samples, the optimal model explaining fish occurrence included water current velocity $(t=-5.36, d f=90, P<0.0001)$ and turbidity $(t=-5.36$, $d f=90, P<0.0001)$, whereas for the beach seine samples, only current velocity $(t=4.24, d f=90, P<0.0001)$ was retained as a significant predictor (Table 2). Hour of the day and winter sampled as well as an interaction term with velocity and turbidity were not significant (Table 2). The best-fit models for fish presence/absence by gear type exhibit inverse relationships with water current velocity; during flood tides, probabilities of occurrence increased on flood tides in the Kodiak trawls and during ebb tides in the beach seines (Fig. 4a). While the flood-ebb tidal asymmetry in delta smelt occurrence was also apparent during the nighttime, the overall catch was much lower. Cumulative frequency distributions of fish catch over time indicate that more delta smelt were caught in the Kodiak trawls before mid-day, whereas they more frequently appeared in the beach seines later in the afternoon and evening (Fig. 4b).

\section{Discussion}

Our results from two sampling periods in consecutive years indicate that during winter, delta smelt aggregate near frontal zones at the shoal-channel interface moving laterally into the shoals on ebb tides and back into the channel on flood tides. For a small pelagic fish attempting to migrate upriver against strong river flows and tidal currents, this behavioral strategy would facilitate either maintaining position or moving upriver during flood tides, whereas on ebb tides, it would help to minimize advection down-estuary. Delta smelt have been shown to prefer modest swimming velocities and a discontinuous stroke and glide behavior in the laboratory, prompting Swanson et al. (1998) to suggest that selective tidal stream transport would be likely employed during the spawning migration. Sommer et al. (2011) using a particle-tracking
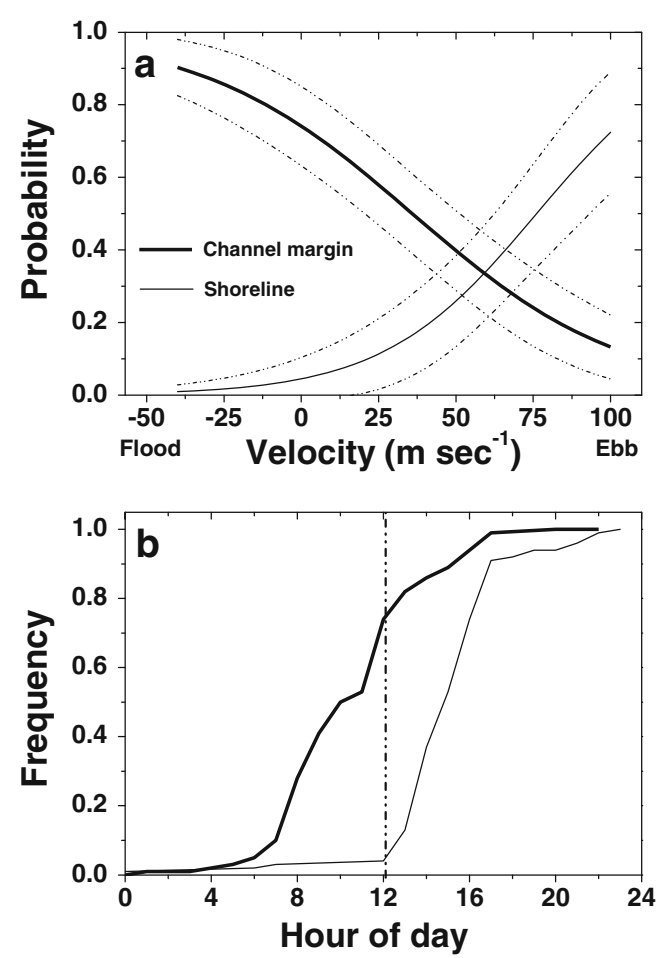

Fig. 4 Generalized linear model fits of delta smelt occurrence to tidal velocity (a) and cumulative distributions of catch relative to sampling hour of the day (b) at the shoal-channel margin (thick line) and near the shoreline (thin line) with $95 \%$ confidence limits, respectively, from the December 2010 field sampling in the Sacramento River 
model showed that moving upriver was only plausible if fish exhibited tidally selective vertical movements; simulating lateral migration was not possible with their one-dimensional vertically averaged model. Indeed, given the small body size, observed swimming behaviors, and extreme flow velocities typically observed on ebb tides during storms $\left(>1,500 \mathrm{~m}^{3} \mathrm{~s}^{-1}\right)$, it is unlikely that vertical tidal movements would facilitate migration. Although fewer delta smelt were caught during the night, the same tidal asymmetry was evident in the catch. Delta smelt are visual foragers, thus are more highly aggregated nearer the surface during the daytime (Hobbs et al. 2006). Lower catch at night is likely due to these fish being more dispersed throughout the water column in darkness, a pattern also observed for larval smelt in the low-salinity zone (Bennett et al. 2002). Such higher dispersion is sufficient to lower catch efficiency of the Kodiak trawl net at night which samples only the upper portion of the water column.

These results also indicate the effectiveness of tuning our sampling routine closely to the scales of the processes in question. Standard monitoring surveys that sample monthly across a fixed sample grid, irrespective of the tides, may be useful for detecting trends in distribution or abundance over many years, but they are hampered by considerable observational bias due to tidal aliasing and are thus not sufficient for addressing finer-scale or process-oriented questions. By focusing our sampling close to the shoal-channel interface, we detected (caught) delta smelt in $82 \%$ (station D, Fig. 1) of net tows during flood tides, whereas detections declined to $67 \%$ at the nearby mid-channel station (X, Fig. 1). Moreover, improving our understanding of how these fish interact with the tides also provides key information on the microhabitat preferences and behaviors essential for adapting monitoring programs, and management options for delta smelt and other pelagic fishes in tidally dominated systems.

The apparent selective tidal movements may also be in response to lateral turbidity gradients that can develop near slack water (Yu et al. 2012). In the shoals, shallow depths and slower tidal currents due to increased friction with the shoreline substantially reduces momentum, such that currents switch direction in the shallows before changing in the center of the river channel (by as much as about an hour) where it is deeper and currents are stronger. This temporal asynchrony in tidal timing, in the presence of a prominent along-channel turbidity gradient in the Sacramento River, can produce lateral turbidity gradients near slack water (Fig. 5). When the turbidity source for the along-channel gradient switches from downestuary in Suisun Bay before the first flush to upriver in the Delta afterwards, inverse patterns in these lateral turbidity gradients are produced with respect to the tides (Fig. 5). Before first flush, as the ebb tide begins, relatively clear water moves downriver along the shoals before it appears in the channel (Fig. 5(a)); on the flood, the reverse occurs with water of higher turbidity moving upriver near shore before the channel (Fig. 5(b)). Thus, if fish attempt to remain with turbid water, they are likely to move upriver near the shoals first and then in the channel as the flood develops, but then travel back down-estuary on the ebb, because clearer water arrives in the shoals first which discourages lateral movement. After first flush,
Fig. 5 Conceptual diagram showing how cross-channel gradients in water turbidity (shaded) develop from temporal asynchronies in near-shore versus mid-channel tidal velocities near slack water (line, vector arrows), as well as how these gradient patterns reverse when the source of turbidity along-channel switches from down-estuary to upriver, before $(\mathbf{a}, \mathbf{b})$ and after (c, d) the first-flush winter rainstorm

\section{Ebb}

Before First-flush

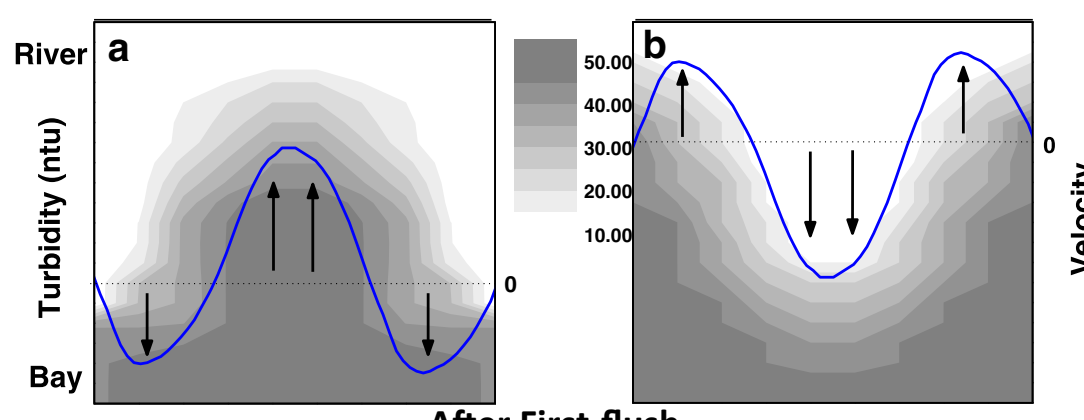

After First-flush

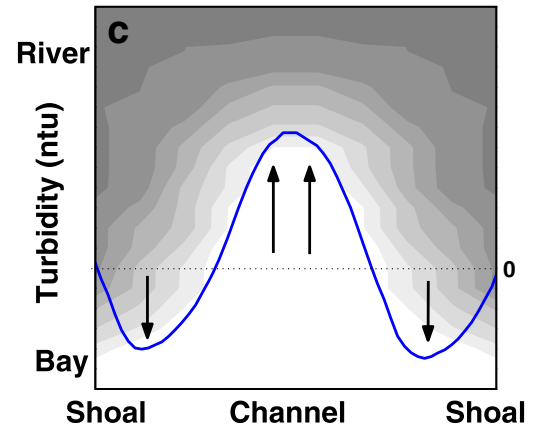

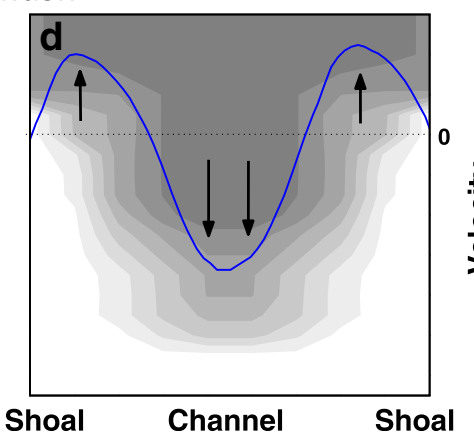


the turbidity source is from upriver, which then reverses both the along-channel and lateral gradients (Fig. 5(c, d)). Now, as the flood tide begins, water in the channel remains turbid while clearer water from down-estuary arrives in the shoals first which discourages onshore movements by fish such that they remain in the turbid channel and move upriver with the tide (Fig. 5(d)). Thus, after the first flush, the coherence of lateral turbidity gradient and tidal current allows fish to greatly reduce the energy needed to swim upriver, even if they are only attempting to remain in turbid water as the tide changes direction.

Our results, thus far, cannot distinguish the relative importance of turbidity versus changing tidal direction as cues for moving laterally or for the spawning migration. Selective tidal movements are a common strategy among marine and estuarine organisms (e.g., review by Forward and Tankersley 2001); however, little is known concerning if or how individuals detect tidal currents and direction (Chapman et al. 2013), with the possible exception of blue crab (Callinectes sapidus) larvae (Forward et al. 2003). Related strategies for migrating have been reported for sockeye salmon (Hinch and Rand 2000) and Pallid sturgeon (McElroy et al. 2012). For delta smelt with a primarily annual life cycle, the advantages of moving laterally are likely to vary greatly given the high interannual variability in freshwater outflows. Extremely high outflow in wet years can weaken or completely overwhelm the flood tidal signal in the Sacramento River and thus preclude or impair maturation and the reproductive output of spawning individuals (Kinnison et al. 2001; Bronmark et al. 2008). In such years, fish may choose to reproduce in suboptimal habitat or migrate up the San Joaquin River which has lower outflows, but this increases potential mortality by moving fish toward the water export facilities (Grimaldo et al. 2009). Nonetheless, there is likely strong selection pressure to use both cues for moving laterally, such that adaptive responses to turbid water by individuals may underlie observations at the population level suggesting that it is a cue for the spawning migration (Grimaldo et al. 2009). When considered in the cost-benefit trade-off proposed by Bronmark et al. (2008), turbidity may sufficiently reduce predation risks relative to potential growth and reproductive benefits, tipping the balance in favor of migrating. Understanding these processes may facilitate development of management tools using turbidity to reduce entrainment impacts not only on imperiled species, such as delta smelt, but also on others occurring in highly dynamic systems subjected to human interventions and future changes in climate.

Acknowledgments We would like to thank the many biologists and technicians for the field assistance with the California Water Science Center and Columbia River Research Laboratory of the U.S. Geological Survey, U.S. Fish and Wildlife Service, Interagency Ecological Program for the San Francisco Estuary, California Department of Fish and Game, and University of California, Davis. For the help with ESA permission and compliance, we thank E. Gleason (USFWS) and D. Hampton (U.S.
National Marine Fisheries Service). Considerable help with planning and logistics was provided by N. Adams, G. Rutz, and V. Orsini (CRRL), J. Adib-Samii and R. Baxter (CDFG), Larry Brown and D. Schoellhamer (USGS), J. Netto (USFWS), L. Grimaldo (USBR), A. Mueller-Solger (IEP), and T. Sommer (California Department of Water Resources). We thank B. McElroy and an anonymous reviewer for the helpful comments. Funding was provided by E. Van Nieuwenhuyse and M. Chotkowski, U.S. Bureau of Reclamation and facilitated by A. Castle and D. Nawi, U.S. Department of the Interior.

Open Access This article is distributed under the terms of the Creative Commons Attribution License which permits any use, distribution, and reproduction in any medium, provided the original author(s) and the source are credited.

\section{References}

Anderson, J.J., and W.N. Beer. 2009. Oceanic, riverine, and genetic influences on spring Chinook salmon migration timing. Ecological Applications 19: 1989-2003.

Bennett, W.A. 2005. Critical assessment of the delta smelt population in the San Francisco Estuary, California. San Francisco Estuary and Watershed Science. Available at http://repositories.cdlib.org/jmie/ sfews/vol3/iss2/art1/. Accessed 2 Sep 2008.

Bennett, W.A., W.J. Kimmerer, and J.R. Burau. 2002. Plasticity in vertical migration by native and exotic estuarine fishes in a dynamic lowsalinity zone. Limnology and Oceanography 47: 1496-1507.

Bergamaschi, B.A., K.M. Kuivila, and M.S. Fram. 2001. Pesticides associated with suspended sediments entering San Francisco Bay following the first major storm of water year 1996. Estuaries 24: $368-380$

Brodersen, J., P.A. Nilsson, J. Ammitzboll, L.-A. Hansson, C. Skov, and C. Bronmark. 2008a. Optimal swimming speed in heads currents and effects on distance movement of winter-migrating fish. PloS One 3(5): e2156. doi:10.1371/journal.pone.0002156.

Brodersen, J., P.A. Nilsson, L.A. Hansson, C. Skov, and C. Bronmark. 2008b. Condition-dependent individual decision-making determines cyprinid partial migration. Ecology 89: 1195-1200.

Bronmark, C., C. Skov, J. Brodersen, P.A. Nilsson, and L.A. Hansson. 2008. Seasonal migration determined by a tradeoff between predator avoidance and growth. PLOS ONE 3: e1957.

Chapman, B.B., A. Eriksen, H. Baktoft, J. Brodersen, P.A. Nilsson, K. Hulthen, C. Bronmark, L.A. Hansson, P. Gronkjaer, and C. Skov. 2013. A foraging cost of migration for a partially migratory cyprinid fish. PLOS ONE 8: e61223.

Coz, J.L., G. Pierrefeu, and A. Paquier. 2008. Evaluation of river discharges monitored by a fixed side-looking Doppler profiler. Water Resources Research 44: W00D09. doi:10.1029/2008WR006967.

Crossin, G.T., S.G. Hinch, A.P. Farrell, D.A. Higgs, A.G. Lotto, J.D. Oakes, and M.C. Healey. 2004. Energetics and morphology of sockeye salmon: Effects of upriver migratory distance and elevation. Journal of Fish Biology 65: 788-810.

Dahl, J., J. Dannewitz, L. Karlsson, E. Petersson, A. Lof, and B. Ragnarsson. 2004. The timing of spawning migration: Implications of environmental variation, life history, and sex. Canadian Journal of Zoology 82: 1864-1870.

Dingle, H. 1996. Migration: The biology of life on the move. New York: Oxford University Press.

Feyrer, F., M.L. Nobriga, and T.R. Sommer. 2007. Multi-decadal trends for three declining fish species: Habitat patterns and mechanisms in the San Francisco estuary, California. U.S.A. Canadian Journal of Fisheries and Aquatic Sciences 64: 723-734. 
Fischer, H.B., E.J. List, R.C.Y. Koh, J. Imberger, and N.H. Brooks. 1979. Mixing in inland and coastal waters. San Diego, CA: Academic.

Forsythe, P.S., K.T. Scribner, J.A. Crossman, A. Ragavendran, E.A. Baker, C. Davis, and K.K. Smith. 2012. Environmental and lunar cues are predictive of the timing of river entry and spawning-site arrival in the lake sturgeon Acipenser fulvescens. Journal of Fish Biology 81: 35-53.

Forward, R.B., and R.A. Tankersley. 2001. Selective tidal stream transport of marine animals. Oceanography and Marine Biology 39: 305-353.

Forward, R.B., R.A. Tankersley, and J.M. Welch. 2003. Selective tidalstream transport of the blue crab Callinectes sapidus: An overview. Bulletin of Marine Science 72: 347-365.

Grimaldo, L.F., P.B. Moyle, T. Sommer, N. Van Ark, G. Jones, E. Holland, P. Smith, and B. Herbold. 2009. The effects of largescale water diversions in a freshwater tidal estuary: Can fish losses be managed? North American Journal of Fisheries Management 29: $1253-1270$

Hobbs, J.A., W.A. Bennett, and J. Burton-Hobbs. 2006. Assessing nursery habitat quality for native fishes in the low-salinity zone of the San Francisco estuary, California. Journal of Fish Biology 69: 907922.

Hinch, S., and P. Rand. 1998. Swim speeds and energy use of uprivermigrating sockeye salmon (Oncorhynchus nerka): Role of local environment and fish characteristics. Canadian Journal of Fisheries and Aquatic Sciences 55: 1821-1831.

Hinch, S., and P. Rand. 2000. Optimal swimming speeds and forwardassisted propulsion: Energy-conserving behaviors of uprivermigrating adult salmon. Canadian Journal of Fisheries and Aquatic Sciences 57: 2470-2478.

Jonsson, B., and N. Jonsson. 1993. Partial migration: Niche shift versus sexual maturation in fishes. Reviews in Fish Biology and Fisheries 3: $348-365$

Jonsson, B., and N. Jonsson. 2006. Life-history effects of migratory costs in anadromous brown trout. Journal of Fish Biology 69: 860-869.

Jonsson, N., B. Jonsson, and L.P. Hansen. 1997. Changes in proximate composition and estimates of energetic costs during upstream migration and spawning in Atlantic salmon Salmo salar. Journal of Animal Ecology 66: 425-436.

Jorgensen, C., E.S. Dunlop, A.F. Opdal, and O. Fiksen. 2008. The evolution of spawning migrations: State dependence and fishinginduced changes. Ecology 89: 3436-3448.

Keefer, M.L., C.C. Caudill, C.A. Perry, and M.L. Moser. 2013. Contextdependent diel behavior of upstream-migrating anadromous fishes. Environmental Biology of Fishes 96: 691-700.

Kimmerer, W.J. 2008. Losses of Sacramento River Chinook salmon and delta smelt to entrainment in water diversions in the Sacramento San Joaquin Delta. San Francisco Estuary Watershed Science. Available at http://repositories.cdlib.org/jmie/sfews/vol6/iss2/art2/. Accessed 13 Oct 2008

Kinnison, M., M. Unwin, A. Hendry, and T. Quinn. 2001. Migratory costs and the evolution of egg size and number in introduced and indigenous salmon populations. Evolution 55: 1656-1667.

Lund, J., E. Hanak, W. Fleenor, W.A. Bennett, R. Howitt, J. Mount, and P. Moyle. 2010. Comparing futures for the Sacramento-San Joaquin Delta. Berkeley: University of California Press.
Maravelias, C.D., and D.G. Reid. 1997. Identifying the effects of oceanographic features and zooplankton on prespawning herring abundance using generalized additive models. Marine Ecology Progress Series 147: 1-9.

Marchand, C., Y. Simard, and Y. Gratton. 1999. Concentration of capelin (mallotus villosus) in tidal upwelling fronts at the head of the Laurentian channel in the St. Lawrence estuary. Canadian Journal of Fisheries and Aquatic Sciences 56: $1832-1848$

McElroy, B., A. DeLonay, and R. Jacobson. 2012. Optimum swimming pathways of fish spawning migrations in rivers. Ecology 93: 29-34.

Moyle, P.B., B. Herbold, D.E. Stevens, and L.W. Miller. 1992. Life history of delta smelt in the Sacramento-San Joaquin Estuary, California. Transactions of the American Fisheries Society 121: 67-77.

Nidzieko, N.J., J.L. Hench, and S.G. Monismith. 2009. Lateral circulation in well-mixed and stratified flows with curvature. Journal of Physical Oceanography 39: 831-851.

Owen, R.W. 1981. Fronts and eddies in the sea: Mechanisms, interactions and biological effects. In Analysis of marine ecosystems, ed. A.R. Longhurst, 197-233. New York: Academic.

Quinn, T.P., and D.J. Adams. 1996. Environmental changes affecting the migratory timing of American shad and sockeye salmon. Ecology 77: 1151-1162.

Rakowitz, G., B. Berger, J. Kubecka, and H. Keckeis. 2008. Functional role of environmental stimuli for the spawning migration in Danube nase Chondrostoma nasus (L.). Ecology of Freshwater Fish 17: $502-514$.

Roff, D.A. 1988. The evolution of migration and some life history parameters in marine fishes. Environmental Biology of Fishes 22: $133-146$

Roff, D.A. 1992. The evolution of life histories. London: Chapman and Hall.

Ruhl, C. A., M.R. Simpson. 2005. Computation of Discharge Using the Index-velocity Method in Tidally Affected Areas, U.S. Geological Survey Scientific Investigations Report. 2005-5004. Available at http://pubs.usgs.gov/sir/2005/5004/. Accessed 10 Jan 2013.

Ruhl, C.A., D.H. Schoellhamer, R.P. Stumpf, and C.L. Lindsay. 2001. Use of remote sensing images of San Francisco Bay to analyze suspended-sediment concentrations. Estuarine, Coastal and Shelf Science 53: 801-812.

Schaffer, W.M., and P.F. Elson. 1975. The adaptive significance of variation in life history among local populations of Atlantic salmon in North America. Ecology 56: 577-590.

Sommer, T., F. Mejia, M. Nobriga, F. Feyrer, and L. Grimaldo. 2011. The spawning migration of delta smelt in the upper San Francisco Estuary. San Francisco Estuary and Watershed Science. Available at http://repositories.cdlib.org/jmie/sfews/ vol9/iss2/art2/. Accessed 1 Sep 2011.

Swanson, C., P.S. Young, and J.J. Cech. 1998. Swimming performance of delta smelt: maximum performance, and behavioral and kinematic limitations on swimming at submaximal velocities. Journal of Experimental Biology 201: 333-345.

Yu, Q., Y.P. Wang, B. Flemming, and S. Gao. 2012. Tide-induced suspended sediment transport: depth-averaged concentrations and horizontal residual fluxes. Continental Shelf Research 34: 53-63. 